\title{
TGF $\beta$-mediated suppression of CD248 in non-cancer cells via canonical Smad-dependent signaling pathways is uncoupled in cancer cells
}

\author{
Sahana Suresh Babu' ${ }^{1}$ Y Yanet Valdez ${ }^{1}$, Andrea Xu' , Alice M O'Byrne ${ }^{1}$, Fernando Calvo ${ }^{2,3}$, Victor Lei ${ }^{1}$ \\ and Edward M Conway ${ }^{1 *}$
}

\begin{abstract}
Background: CD248 is a cell surface glycoprotein, highly expressed by stromal cells and fibroblasts of tumors and inflammatory lesions, but virtually undetectable in healthy adult tissues. CD248 promotes tumorigenesis, while lack of CD248 in mice confers resistance to tumor growth. Mechanisms by which CD248 is downregulated are poorly understood, hindering the development of anti-cancer therapies.
\end{abstract}

Methods: We sought to characterize the molecular mechanisms by which CD248 is downregulated by surveying its expression in different cells in response to cytokines and growth factors.

Results: Only transforming growth factor (TGF $\beta$ ) suppressed CD248 protein and mRNA levels in cultured fibroblasts and vascular smooth muscle cells in a concentration- and time-dependent manner. TGF $\beta$ transcriptionally downregulated CD248 by signaling through canonical Smad2/3-dependent pathways, but not via mitogen activated protein kinases p38 or ERK1/2. Notably, cancer associated fibroblasts (CAF) and cancer cells were resistant to TGF $\beta$ mediated suppression of CD248.

Conclusions: The findings indicate that decoupling of CD248 regulation by TGF $\beta$ may contribute to its tumor-promoting properties, and underline the importance of exploring the TGF $\beta$-CD248 signaling pathway as a potential therapeutic target for early prevention of cancer and proliferative disorders.

\section{Background}

CD248, also referred to as endosialin and tumor endothelial marker (TEM-1) [1] (reviewed in [2]), is a member of a family of type I transmembrane glycoproteins containing C-type lectin-like domains, that includes thrombomodulin [3] and CD93 [4]. Although the mechanisms are not fully elucidated, these molecules all modulate innate immunity, cell proliferation and vascular homeostasis and are potential therapeutic targets for several diseases, including cancer, inflammatory disorders and thrombosis.

CD248 is expressed by cells of mesenchymal origin, including murine embryonic fibroblasts (MEF), vascular smooth muscle cells, pericytes, myofibroblasts, stromal cells and osteoblasts [5-12]. During embryonic development, CD248 is prominently and widely expressed in the fetus

\footnotetext{
* Correspondence: ed.conway@ubc.ca

${ }^{1}$ Centre for Blood Research, Department of Medicine, University of British Columbia, 4306-2350 Health Sciences Mall, V6T 1Z3, BC Vancouver, Canada Full list of author information is available at the end of the article
}

(reviewed in [2]). However, after birth, CD248 protein levels are dramatically downregulated [7,13-15], resulting in only minimal expression in the healthy adult, except in the endometrium, ovary, renal glomerulus and osteoblasts [11,16-18].

While largely absent in normal tissues, CD248 is markedly upregulated in almost all cancers. Highest expression is found in neuroblastomas and in subsets of carcinomas, such as breast and colon cancers, and in addition, in glioblastomas and mesenchymal tumors, such as fibrosarcomas and synovial sarcomas $[8,14,15,17,19,20]$, where it is mostly detected in perivascular and tumor stromal cells, but also in the tumor cells themselves [21,22]. CD248 is also expressed in placenta and during wound healing and in wounds such as ulcers. It is also prominently expressed in synovial fibroblasts during inflammatory arthritis [10]. In some tumors and in chronic kidney disease, CD248

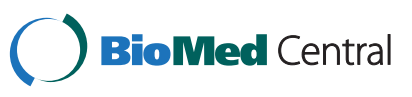

(C) 2014 Suresh Babu et al.; licensee BioMed Central Ltd. This is an Open Access article distributed under the terms of the Creative Commons Attribution License (http://creativecommons.org/licenses/by/2.0), which permits unrestricted use, distribution, and reproduction in any medium, provided the original work is properly credited. The Creative Commons Public Domain Dedication waiver (http://creativecommons.org/publicdomain/zero/1.0/) applies to the data made available in this article, unless otherwise stated. 
expression directly correlates with worse disease and/or a poor prognosis $[9,23,24]$. The contributory role of CD248 to these pathologies was confirmed in gene inactivation studies. Mice lacking CD248 are generally healthy, except for an increase in bone mass $[11,25]$ and incomplete postnatal thymus development [26]. However, in several models, they are protected against tumor growth, tumor invasiveness and metastasis [25,27] and they are less sensitive to anti-collagen antibody induced arthritis [10].

While the mechanisms by which CD248 promotes tumorigenesis and inflammation are not clearly defined, the preceding observations have stimulated interest in exploring CD248 as a therapeutic target, primarily by using anti-CD248 antibodies directed against its ectodomain $[19,20,28,29]$. Likely due to limited knowledge of CD248 regulatory pathways, other approaches to interfere with or suppress CD248 have not been reported. CD248 is upregulated in vitro by high cell density, serum starvation, by the oncogene v-mos [5] and by hypoxia [30]. We previously showed that fibroblast expression of CD248 is suppressed by contact with endothelial cells [27]. Otherwise, factors which down-regulate CD248 have not heretofore been reported, yet such insights might reveal novel sites for therapeutic intervention.

In this study, we evaluated the effects of several cytokines on the expression of CD248. We show that TGF $\beta$ specifically and dramatically downregulates CD248 expression in normal cells of mesenchymal origin and that this is mediated via canonical Smad-dependent intracellular signaling pathways. Notably, cancer cells and cancer associated fibroblasts are resistant to TGF $\beta$ mediated suppression of CD248. The findings suggest that CD248 not only promotes tumorigenesis, but may be a marker of the transition of TGF $\beta$ from a tumor suppressor to a tumor promoter. Delineating the pathways that couple TGF $\beta$ and CD248 may uncover novel therapeutic strategies.

\section{Methods \\ Reagents}

Rabbit anti-human CD248 antibodies (Cat no \#181601AP) were from ProteinTech (Chicago, USA); goat antihuman actin antibodies (\#sc-1616) from Santa Cruz (USA); rabbit anti-SMAD1,5-Phospho (Cat no \#9516), rabbit anti-Smad2-Phospho (\#3101), rabbit anti-ERK1/2phospho (\#9101S), rabbit anti-p38-phospho (\#9211), rabbit anti-SMAD2/3 (\#5678) and rabbit anti-SMAD3 (\#9513) were from Cell Signaling (USA). Murine antirabbit $\alpha$-smooth muscle actin monoclonal antibodies (\#A5228) were from Sigma-Aldrich (Canada). Secondary antibodies included goat anti-rabbit IRDye 800 (LIC-92632211). Goat anti-rabbit IRDye 680 (LIC-926-68071) or donkey anti-goat IRDye 680 antibodies (LIC-92668024) and anti-rabbit Alexa green-488 were from Licor (Nebraska, USA).
Basic fibroblast growth factor (bFGF), recombinant human transforming growth factor $\beta-1$ (TGF $\beta)(240-B / C F)$, recombinant human bone morphogenic protein (BMP-2) (355-BM-010/CF), recombinant human/mouse/Rat Activin A, CF (338-AC-010/CF), recombinant rat platelet derived growth factor-BB (PDGF) (250-BB-050), recombinant human vascular endothelial growth factor (VEGF), and recombinant mouse interleukin-6 (IL-6) (406-ML/CF), recombinant mouse tumor necrosis factor- $\alpha$ (TNF- $\alpha$ ) (410-MT/CF) and recombinant mouse interferon- $\gamma$ (IFN- $\gamma)(485-\mathrm{MI} / \mathrm{CF})$ were purchased from R\&D Systems (Minneapolis, USA). Phorbol 12-Myristate 13-Acetate (PMA) (P1585) and $\alpha$-amanitin were from Sigma-Aldrich (Oakville, Canada). The inhibitors SB431542 (for ALK5), SB202190 (for p38) and U0126 (for ERK1/2) were from Tocris Biosciences, Canada.

\section{Mice}

Transgenic mice lacking CD248 $\left(\mathrm{CD} 248^{\mathrm{KO} / \mathrm{KO}}\right)$ were previously generated and genotyped as described [10]. Mice were maintained on a C57Bl6 genetic background and corresponding sibling-derived wild-type mice $\left(\mathrm{CD} 248^{\mathrm{WT} / \mathrm{WT}}\right)$ were used as controls.

\section{Cell culture}

Murine embryonic fibroblasts (MEF) were isolated from $\mathrm{CD} 248^{\mathrm{WT} / \mathrm{WT}}$ or $\mathrm{CD} 248^{\mathrm{KO} / \mathrm{KO}}$ mice as previously described [10]. Cells were cultured in DMEM (Invitrogen, Canada) with $10 \%$ fetal calf serum (FCS) and 1\% Penicillin/Streptomycin (Invitrogen, Karlsruhe, Germany) and used at passages 2-5. Upon reaching confluence, cells were incubated for $14 \mathrm{hrs}$ in low serum media (1\% FCS) and then treated as indicated in the Results with TGF $\beta(0.1-12 \mathrm{ng} / \mathrm{ml}), \mathrm{BMP}-2$ (50-100 ng/ml), PDGF (50 ng/ml), VEGF (20 ng/ml), bFGF (10 ng/ml), IL-6 $10 \mathrm{ng} / \mathrm{ml}$ ), PMA (60 ng/ml), SB43152 $(1 \mu \mathrm{M})$, and/or $\alpha$-amanitin $(20 \mu \mathrm{g} / \mathrm{ml})$, for different time periods as noted. Using previously reported methods [31,32], vascular smooth muscle cells (SMC) were isolated from the aortae of CD248 ${ }^{\mathrm{WT} / \mathrm{WT}}$ or $\mathrm{CD} 248^{\mathrm{KO} / \mathrm{KO}}$ pups, cultured in SMC growth media (Promocell, Heidelberg, Germany) with 15\% FCS and 1\% Penicillin/Streptomycin (Invitrogen) and used at passages 2-5. Wehi-231 and A20 (mouse Blymphoma) cell lines (gift of Dr. Linda Matsuuchi, University of British Columbia) were cultured in RPMI media with $10 \%$ fetal calf serum (FCS), 1\% Penicillin/Streptomycin and 0.1\% mercaptoethanol. Normal fibroblasts (NF) derived from normal mouse mammary glands, and cancer associated fibroblasts (CAF) from mammary carcinoma in mice containing the MMTV-PyMT transgene [33] were provided by Dr. Erik Saha (Cancer Research London UK Research Institute, London, UK), and cultured in DMEM with $10 \%$ FCS, $1 \%$ Penicillin/Streptomycin and 1\% insulin-transferrinselenium. 


\section{Protein electrophoresis and western blotting}

Cells were scraped from culture dishes, suspended in PBS, pelleted by centrifugation and lysed with $50 \mu$ RIPA buffer (30 mM Tris- $\mathrm{HCl}, 15 \mathrm{mM} \mathrm{NaCl}, 1 \%$ Igepal, 0.5\% deoxycholate, $2 \mathrm{mM}$ EDTA, 0.1\% SDS). Centrifugation-cleared lysates were quantified for protein content. Equal quantities of cell lysates $(25 \mu \mathrm{g})$ were separated by SDS-PAGE under reducing or non-reducing conditions as noted, using $8 \%$ and $12 \%$ low-bisacrylamide gels (acrylamide to bis-acrylamide $=118: 1$ ). In pilot studies, these gels provided highest resolution of the bands of interest [34]. Proteins were transferred to a nitrocellulose membrane and after incubating with blocking buffer (1:1 PBS:Odyssey buffer) (Licor, Nebraska, U.S.A.), they were probed with rabbit anti-CD248 antibodies $140 \mu \mathrm{g} / \mathrm{ml}$, goat anti-actin antibodies, rabbit anti-Smad1-Phospho, anti-Smad2-Phospho, anti-Smad2-Total or anti-Smad3 antibodies in blocking buffer overnight. After washing and incubation of the filter with the appropriate secondary antibodies $(100 \mathrm{ng} / \mathrm{ml}$ IRDye 800 goat anti-rabbit or IRDye ${ }^{\circ}$ Donkey anti-goatLicor, Nebraska, USA) in blocking buffer for $1 \mathrm{hr}$ at room temperature, detection was accomplished using a Licor Odyssey imaging system (Licor, Nebraska, USA) and intensity of bands of interest were quantified relative to actin using Licor software (Licor, Nebraska, U.S). All studies were performed a minimum of 3 times, and representative Western blots are shown.

\section{Immunofluorescence analysis}

Preconfluent cells were grown on cover slips and fixed at room temperature with acetone (100\%) for 2 minutes, followed by a 30 minute incubation with blocking buffer (1\% BSA in PBS). Cells were then incubated with antiCD248 rabbit antibodies $40 \mu \mathrm{g} / \mathrm{ml}$, for $1 \mathrm{hr}$ followed by extensive washes and incubation with Alexa green 488 antirabbit antibody $(5 \mathrm{mg} / \mathrm{ml})$ for $1 \mathrm{hr}$. The cells were washed and fixed with antifade containing DAPI (Invitrogen, Canada) for subsequent imaging with a confocal microscopic (Nikon C2 model, Nikon, Canada).

\section{Determination of stability of CD248 mRNA}

$\alpha$-Amanitin, an inhibitor of RNA-polymerase II, was used to quantify the half-life of CD248 mRNA using previously reported methods [35]. Briefly, 90\% confluent MEF were incubated with DMEM with $1 \%$ fetal calf serum (FCS) overnight, after which the media was refreshed, and subsequently stimulated with $\alpha$-Amanitin $20 \mu \mathrm{g} / \mathrm{ml} \pm \mathrm{TGF} \beta$ for the indicated time periods. RNA was isolated for gene expression analysis.

\section{Gene expression analysis}

RNA was isolated from the MEF and reverse transcribed to cDNA/mRNA according to the manufacturer's instructions (Qiagen RNeasy kit and QuantiTech reverse transcription kit, Hilden, Germany). Expression of CD248 mRNA was analyzed by RT-PCR and quantified with SYBR green using real time PCR (Applied Biosystems ${ }^{\circ}$ Real-Time PCR Instrument, Canada). CD248 mRNA levels were reported relative to the expression of the housekeeping gene, Glyceraldehyde 3-Phosphate dehydrogenase $(\mathrm{GAPDH})$. The following amplification primers were used: CD248 forward (5'-GGGCCCCTACCACTCCTCAGT-3'); CD248 reverse (5'-AGGTGGGTGGACAGGGCTCAG-3'); GAPDH forward (5'-GACCACAGTCCATGCCATCACT GC-3'); GAPDH reverse (5'-ATGACCTTGCCCACAGC CTTGG-3').

\section{Animal care}

Experimental animal procedures were approved by the Institutional Animal Care Committee of the University of British Columbia.

\section{Statistics}

Experiments were performed in triplicate and data were analyzed using Bonferroni post-test to compare replicates (GraphPad Prism software Inc, California, USA). Error bars on figures represent standard errors of the mean (SEM). $\mathrm{P}<0.05$ was considered statistically significant.

\section{Results}

Screen for cytokines that modulate expression of CD248

In view of the established links between CD248 and cell proliferation, migration and invasion, we screened a number of growth factors, cytokines and PMA for effects on the expression of CD248 by MEF. These factors and the chosen concentrations were selected based on the fact that all reportedly induce MEF to undergo inflammatory, migratory and/or proliferative changes. We previously determined that these cells express CD248 at readily detectable levels, as assessed by Western blot, where it is often seen as a monomer $(\sim 150 \mathrm{kDa})$ and a dimer $(\sim 300 \mathrm{kDa})$. An incubation time of $48 \mathrm{hrs}$ was chosen based on our previous findings that CD248dependent release and activation of matrix metalloproteinase (MMP9) induced by TFG $\beta$ was observed over that period [10]. As seen in Figure 1A, bFGF, VEGF, PDGF, PMA, IL- 6 , TNF- $\alpha$, and IFN- $\gamma$ had no effects on CD248 expression. However, TGF $\beta$ suppressed expression of CD248 in MEF to almost undetectable levels (Figure 1A). The same pattern of response was evident in the murine fibroblast cell line $10 \mathrm{~T} 1 / 2$ (Figure 1B), and in mouse primary aortic smooth muscle cells (SMC) (Figure 1C), suggesting that CD248 specifically responds to TGF $\beta$ and that the response is active in diverse cell lines. 


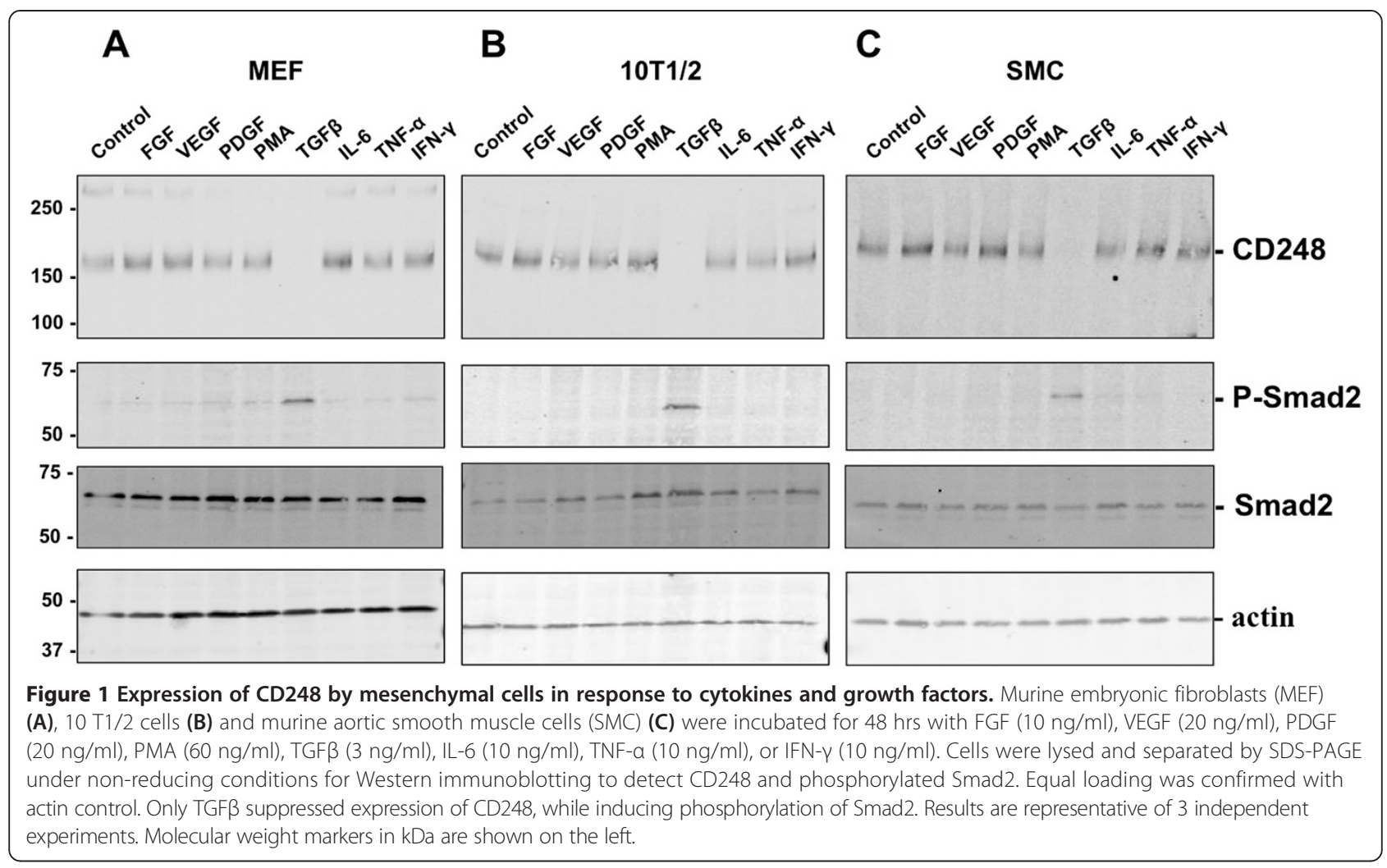

\section{TGF $\beta$ suppresses expression of CD248 by MEF}

TGF $\beta$ exerts a range of cellular effects by binding to and activating its cognate serine/threonine kinase receptors, TGF $\beta$ type I (TGF $\beta R I, A L K-5)$ and type II (TGF $\beta$ RII), which in turn mediate intracellular signaling events via canonical Smad-dependent and Smad-independent signaling pathways (e.g. p38 mitogen-activated protein kinase (MAPK) pathway) (for reviews [36-38]). The canonical Smad-dependent pathway results in recruitment and phosphorylation of Smad2 and Smad3 which complex with Smad4 to enter the nucleus and form a transcriptional complex that modulates target gene expression in a context-dependent manner. Diversity in the response to TGF $\beta$ signaling is achieved by Smad2/3-independent, "non-canonical" signaling pathways, which may include, among others, activation of combinations of mitogenactivated protein kinases ERK1/2 and p38, PI3K/Akt, cyclo-oxygenase, Ras, RhoA, Abl and Src (for reviews [36-38]). We characterized the pathways by which TGF $\beta$ suppresses CD248. MEF were exposed to a range of concentrations of TGF $\beta$ ( 0.1 to $12 \mathrm{ng} / \mathrm{ml})$ for a period of $48 \mathrm{hrs}$. Western blots of cell lysates showed that TGF $\beta$ downregulated the expression of CD248 in a concentration-dependent manner. As expected, TGF $\beta$ also induced phosphorylation of Smad2 and Smad3 in a concentration-dependent manner (Figure 2A,B). Confocal microscopy was used to visualize the effects of TGF $\beta$ on expression of CD248 by MEF (Figure 2C). At
48 hrs without TGF $\beta$, CD248 was readily detected on the surface of CD248 ${ }^{\mathrm{WT} / \mathrm{WT}}$ MEF, but was entirely absent in TGF $\beta$-treated cells as well as in CD248 ${ }^{\mathrm{KO} / \mathrm{KO}}$ MEF.

We next evaluated the temporal response of CD248 to a fixed concentration of TGF $\beta$ ( $3 \mathrm{ng} / \mathrm{ml}$ ) (Figure $3 \mathrm{~A}, \mathrm{~B})$ and found that CD248 expression was suppressed in a timedependent manner to $<50 \%$ by $6 \mathrm{hrs}$ of exposure to TGF $\beta$. Once again, TGF $\beta$ induced phosphorylation of Smad2. Notably, as seen in experiments using CD248 ${ }^{\mathrm{KO} / \mathrm{KO}} \mathrm{MEF}$ (lacking CD248) (Figure 3C), CD248 was not required for TGF $\beta$-mediated phosphorylation of Smad2, indicating that CD248 is not a co-receptor for TGF $\beta$ signaling.

\section{TGF $\beta$ suppresses CD248 mRNA accumulation}

We evaluated the mechanism by which TGF $\beta$ suppresses CD248. CD248 mRNA levels in MEF were quantified by qRT-PCR at different time intervals following exposure of the cells to $3 \mathrm{ng} / \mathrm{ml}$ TGF $\beta$. TGF $\beta$ suppressed CD248 mRNA levels in a time-dependent manner and by $75 \mathrm{mi}-$ nutes, mRNA accumulation had diminished to $~ 50 \%$ (Figure 4 ) and was $\sim 20 \%$ by 2 hrs.

Using the RNA polymerase II inhibitor, $\alpha$-amanitin $(20 \mu \mathrm{g} / \mathrm{ml})$, we measured the stability of CD248 mRNA in MEF and assessed whether it is altered by TGF $\beta$. As seen in Figure 4, the time-dependent reduction in CD248 mRNA with $\alpha$-amanitin alone was almost identical to the pattern seen with TGF $\beta$ alone, i.e., the half-life was determined to be approximately 75 minutes. The addition of 

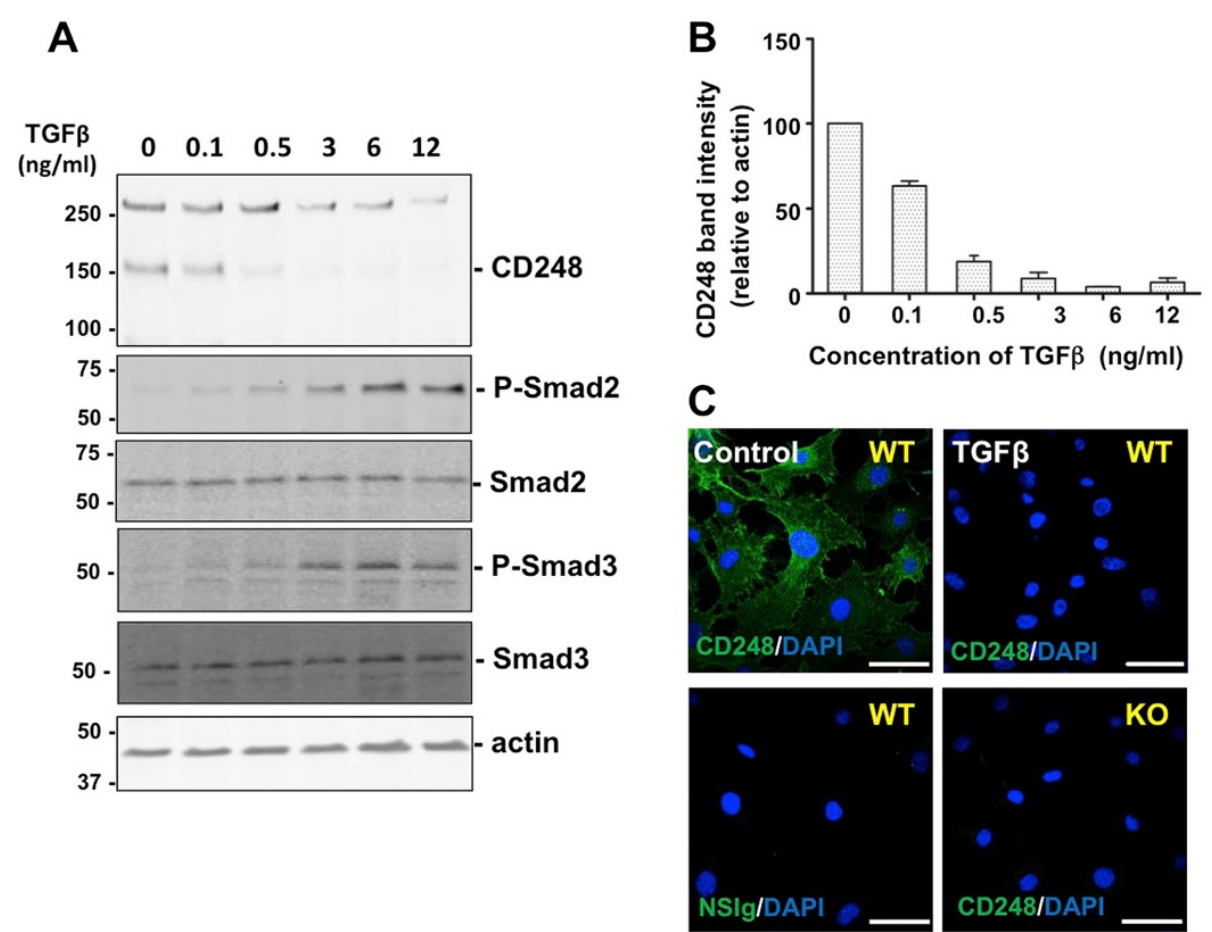

Figure 2 Expression of CD248 in response to increasing concentrations of TGF $\beta$. (A) MEF were incubated for 48 hrs with increasing concentrations of TGF $\beta$. Expression of CD248 (seen as monomers ( $160 \mathrm{kDa}$ ) and dimers) and phosphorylation of Smad2, were detected by Western blot. (B) CD248 expression relative to actin expression was quantified by densitometry ( $\mathrm{n}=3$ experiments) and results were normalized to the no-treatment condition. (C) CD248 expression by MEF (wild-type, WT; or lacking CD248, KO) was detected with specific anti-CD248 antibodies after exposure to carrier (Control) or TGF $\beta$ for 48 hrs. TGF $\beta$ suppresses CD248 in a concentration-dependent manner, with simultaneous increase in phosphorylated Smad2 and ERK1/2. Scale bar $=50 \mu \mathrm{m}$.

TGF $\beta$ to $\alpha$-amanitin did not alter the half-life. The findings suggest that TGF $\beta$ acts primarily at the level of CD248 transcription and does not alter the stability of CD248 mRNA.

\section{Suppression of CD248 by TGF $\beta$ is mediated by ALK-5 signaling} In MEF, TGF $\beta$ reportedly signals exclusively through complexes involving ALK5 [39]. SB431542 is a selective inhibitor of TGF $\beta$ superfamily type I activin receptor-like kinase (ALK) receptors, ALK4, ALK5 and ALK7, which does not affect components of the ERK, JNK, or p38 MAP kinase pathways [40]. We tested whether ALK5 is required for TGF $\beta$-mediated suppression of CD248. MEF were incubated with the inhibitor $(1 \mu \mathrm{M})$ for $1 \mathrm{hr}$ prior to the addition of $3 \mathrm{ng} / \mathrm{ml}$ TGF $\beta$. Expression of CD248 at $48 \mathrm{hrs}$ was assessed by Western blot, immunofluorescence analysis and qRT-PCR (Figure 5A-C). When added alone, neither the inhibitor SB431542 nor its vehicle DMSO, had any effect on CD248 expression. As before, TGF $\beta$ dramatically suppressed CD248, while simultaneously inducing phosphorylation of Smad2 (Figure 5A). This effect of TGF $\beta$ was entirely abrogated by preincubation of the cells with SB431542. Thus, addition of TGF $\beta$ down-regulates CD248 via activation of ALK-5.

TGF $\beta$-mediated suppression of CD248 is independent of ERK $1 / 2$ and $p 38$ signaling

We also tested whether suppression of CD248 expression by TGF $\beta$ is mediated via one or more non-canonical Smad2/3-independent pathways. Using U0126, a specific inhibitor of ERK1/2 phosphorylation [41], we showed that TGF $\beta$ does not rely on signaling via ERK $1 / 2$ to suppress CD248 (Figure 6A). In a similar manner, using the p38 inhibitor, SB202190 [42], we also demonstrated that phosphorylation of p38 is not required for TGF $\beta$ to downregulate expression of CD248 (Figure 6B). Thus, in MEF, TGF $\beta$ suppresses CD248 expression via signaling pathways that do not require activation of these two Smad2/3-independent pathways.

\section{Regulation of CD248 by Bone morphogenic protein 2 (BMP2) and Activin}

The TGF $\beta$ family of cytokines comprises over 35 members, including the prototypic TGF $\beta$ isoforms (TGF $\beta 1$, $\beta 2, \beta 3$ ), bone morphogenic proteins (BMPs), growth and differentiation factors, activins and nodal. These regulate 
B
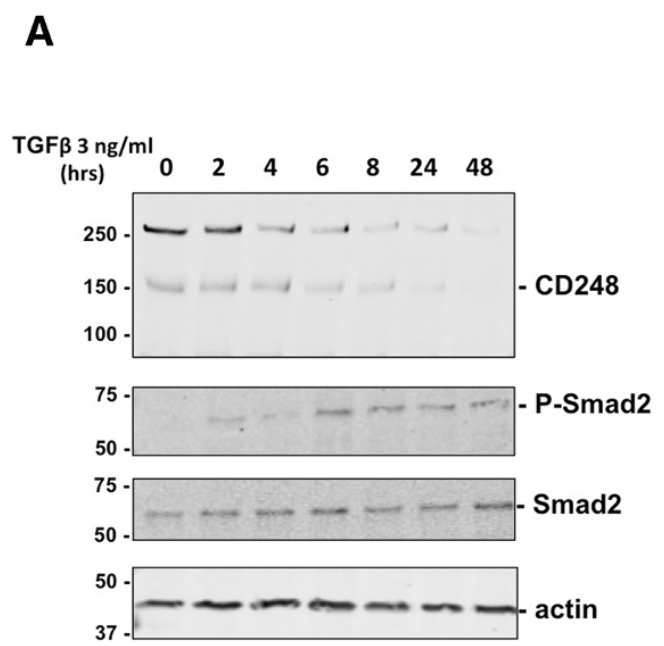
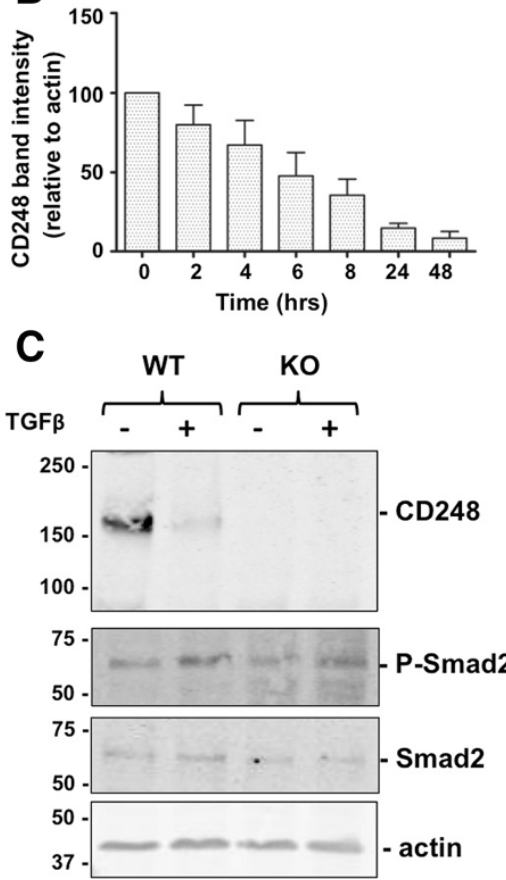

Figure 3 Temporal response of CD248 to TGF $\beta$. (A) MEF were incubated for 0-48 hrs with TGF $33 \mathrm{ng} / \mathrm{ml}$. Expression of CD248 and phosphorylation of Smad2, were detected by Western blot. (B) CD248 expression relative to actin expression was quantified by densitometry ( $\mathrm{n}=3$ experiments) and results were normalized to the no-treatment condition. CD248 expression decreases as Smad2 is phosphorylated. (C) CD248 WTMT (WT) or CD248 ${ }^{\mathrm{KO} / \mathrm{KO}}$ (KO) MEF were exposed to TGF $\beta$ ( 0 or $3 \mathrm{ng} / \mathrm{ml}$ ) for 48 hrs and lysates were Western blotted. Representative blots from 3 experiments are shown. Smad2 and ERK1/2 are phosphorylated in response to TGF $\beta$ even in cells that lack CD248.

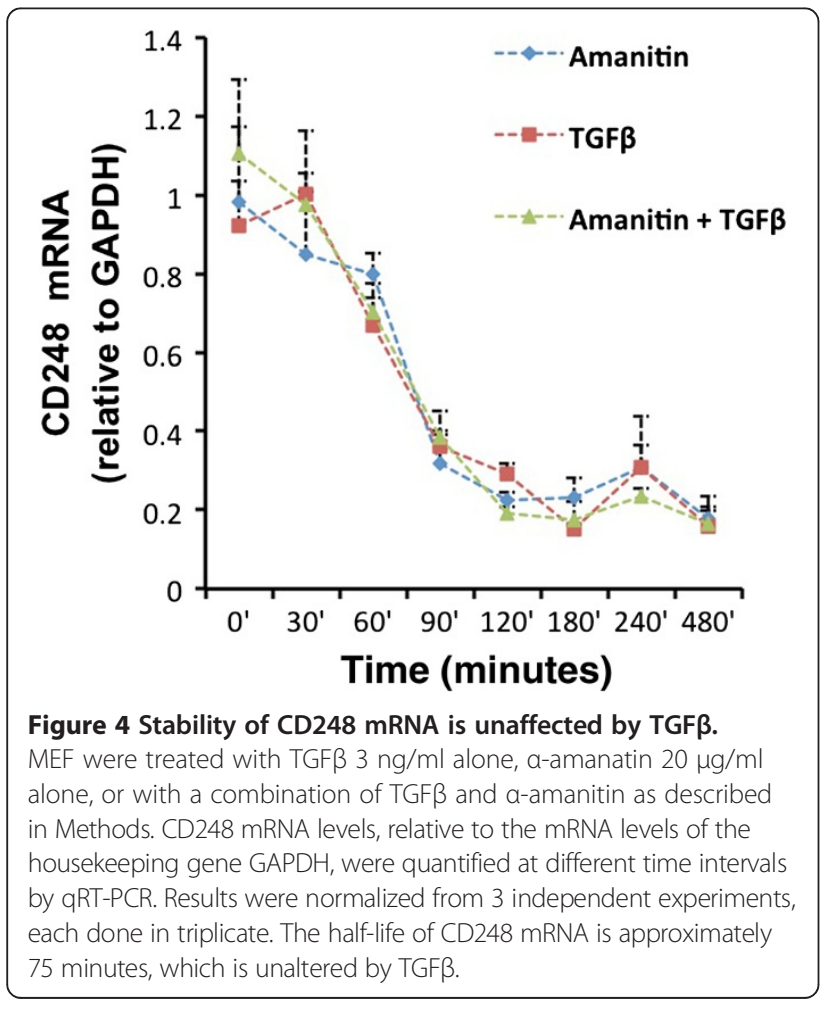

cell survival, proliferation, differentiation, adhesion, migration and death in a cell type-and context-dependent manner. To further assess the specificity of action of TGF $\beta$ on CD248 expression, we tested whether BMP2 and activin had similar effects. MEF were treated for 24 and $48 \mathrm{hrs}$ with 50 and $100 \mathrm{ng} / \mathrm{ml}$ of activin or BMP2 (Figure 7A). At these concentrations of BMP2, Smad1 was, as expected, phosphorylated, while Smad2 was not [43]. Notably, BMP2 had no effect on CD248 expression, and thus does not participate in its regulation under these conditions. Activin induced phosphorylation of Smad2, which reportedly occurs via ALK-4/7 activation [44] (Figure 7B). In contrast to TGF $\beta$, activin caused only a slight reduction in CD248 expression after 48 hrs of exposure.

\section{Cancer cell lines are resistant to TGF $\beta$ suppression of CD248}

Since elevated CD248 is associated with tumorigenesis, we tested whether TGF $\beta$ could suppress CD248 in tumor cell lines as effectively as in the healthy non-cancerous cells examined above. Mouse B lymphoma cell lines, Wehi-231 and A20 were incubated with TGF $\beta$ at concentrations of $3 \mathrm{ng} / \mathrm{ml}$ and $12 \mathrm{ng} / \mathrm{ml}$ for $24 \mathrm{hrs}$ and $48 \mathrm{hrs}$ (Figure 8). Under these conditions, SMAD2 was phosphorylated, with 


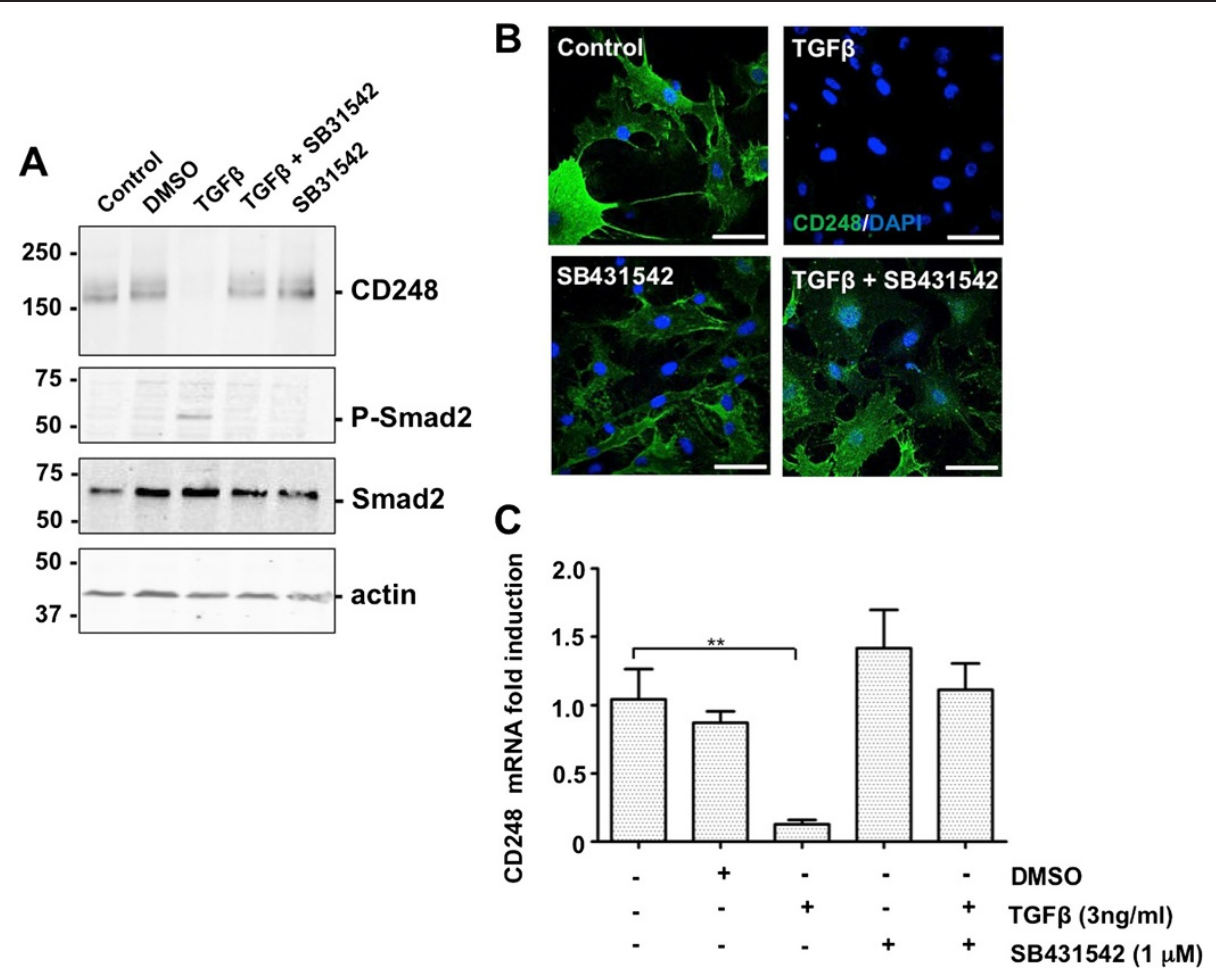

Figure 5 TGF $\beta$-induced suppression of CD248 is mediated via canonical signaling pathways. (A, B, C) MEF were incubated for 48 hrs with TGF $\beta 3 \mathrm{ng} / \mathrm{ml}$ and the ALK-inhibitor SB431542 $1 \mu \mathrm{M}$ either singly or in combination. Controls included carriers for SB431542 (DMSO) or for TGF $\beta$ (0.1\% BSA). (A) Western blots and (B) immunofluorescence were used to detect expression of CD248 (green). (C) CD248 mRNA levels were also quantified ( $n=3$ experiments, each in triplicate; ${ }^{*} p<0.05$ ). Results indicate that TGF $\beta$-mediated suppression of CD248 protein and mRNA requires integrity of canonical ALK5-Smad2 signaling pathway. Scale bar $=50 \mu \mathrm{m}$.
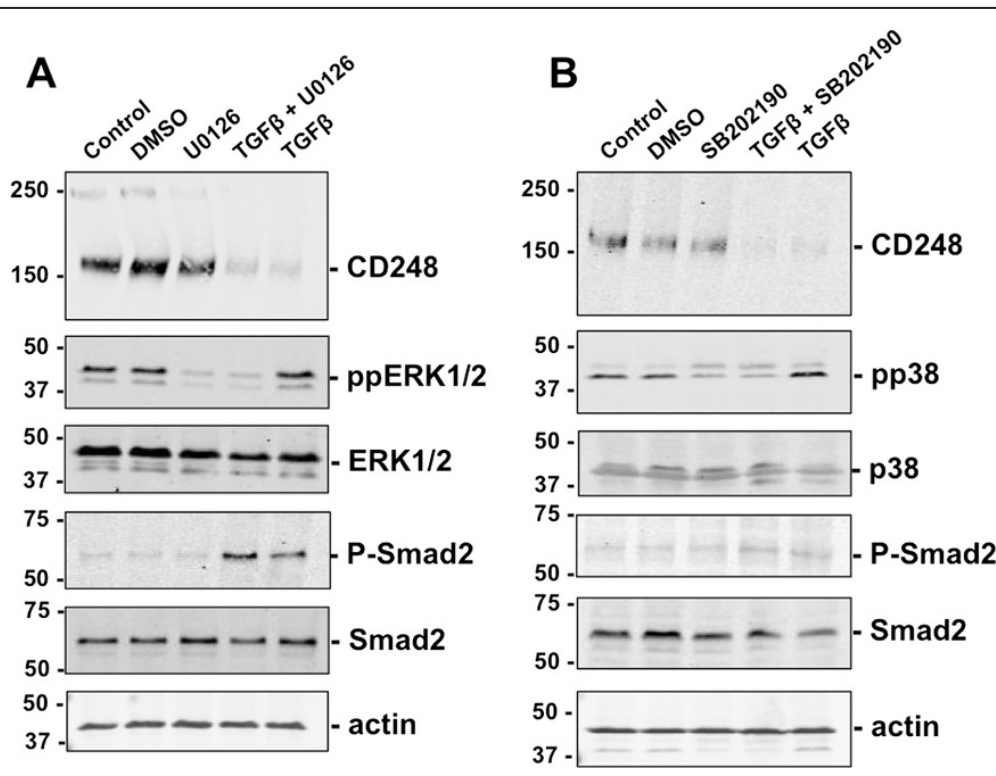

Figure 6 TGF $\beta$-mediated suppression of CD248 via ALK5 is specific. (A, B) MEF were incubated with TGF $\beta$ ( $3 \mathrm{ng} / \mathrm{ml})$ for 48 hrs in the presence or absence of the inhibitor of phosphorylated ERK1/2, U0126 $10 \mu \mathrm{M}$ (A) or phosphorylated p38, SB202190 $10 \mu \mathrm{M}$ (B). Representative Western blots from 3 independent experiments are shown and were used to assess the effect on CD248 expression. TGF $\beta$-coupling to either ERK1/2 or to p38 is not involved in its suppressive effects on CD248. 

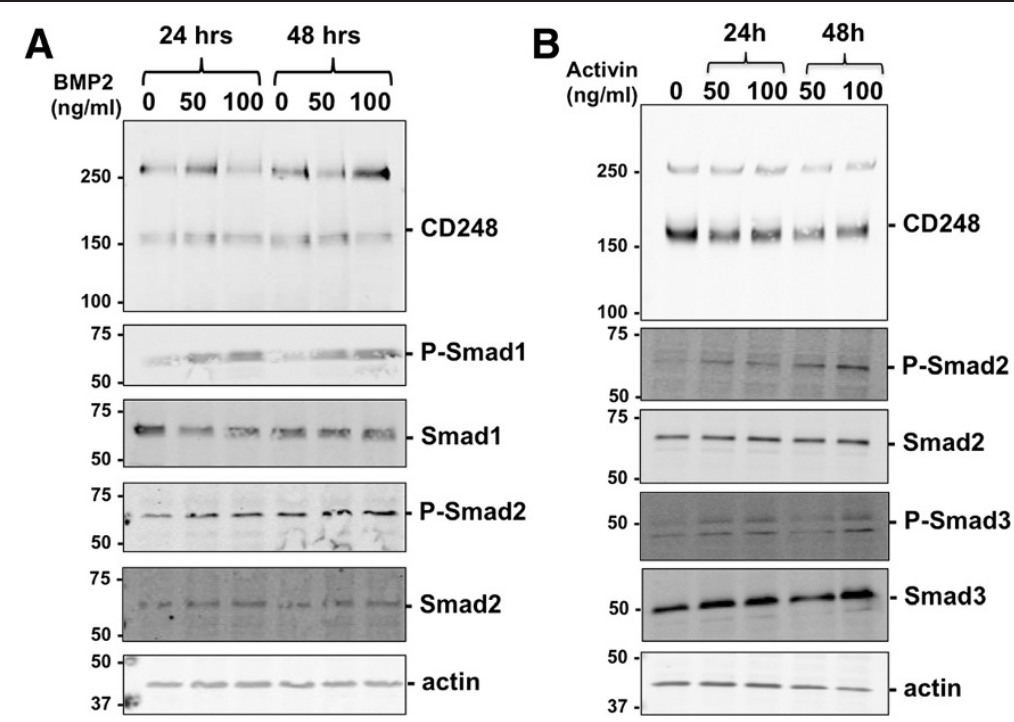

Figure 7 Regulation of CD248 by BMP-2 and Activin. MEF were incubated with different concentrations of BMP2 (A) or activin (B) for 24 or 48 hrs. Representative Western blots from 3 independent experiments are shown and were used to assess the effect on CD248 expression.

minimal effect on Smad3 phosphorylation. In both the Wehi-231 cells (Figure 8A) and the A20 cells (Figure 8B), there was no significant suppression of CD248 expression in response to TGF $\beta$. Indeed, in the latter, there was a slight increase in CD248 in response to the TGF $\beta$.
We also examined the effect of TGF $\beta$ on the expression of CD248 by normal and cancer associated fibroblasts (NF and CAF, respectively) that were derived from mouse mammary tissues [33]. Protein levels of CD248 were relatively low in both of these cell lines, making it difficult to
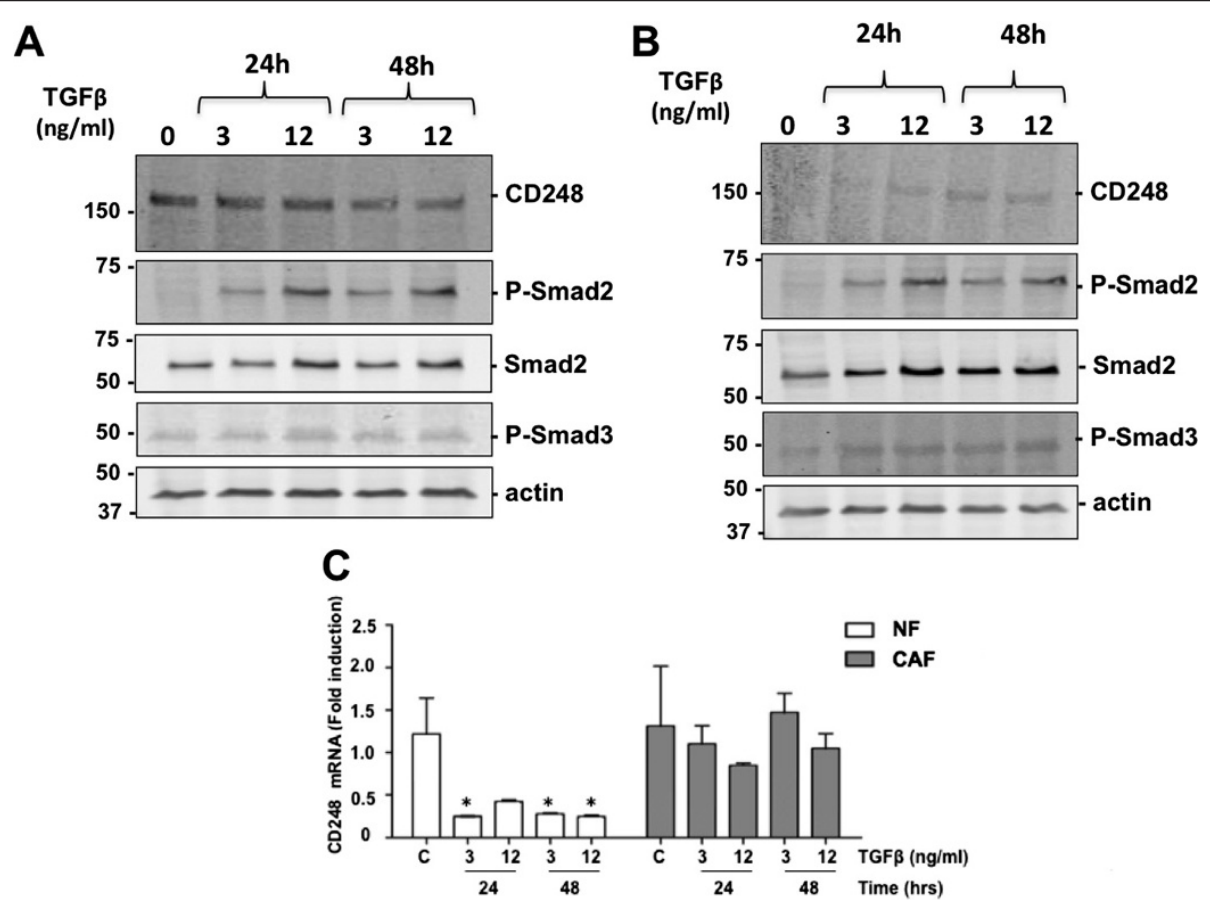

Figure 8 Regulation of CD248 in cancer cells. (A, B) Wehi-231 (A) and A20 (B) mouse lymphoma cells were incubated with different concentrations of TGF $\beta$ for 24 or 48 hrs and lysates were assessed by Western immunoblot. CD248 levels were minimally affected in spite of phosphorylation of Smad2. Results are representative of 3 independent experiments. (C) Normal fibroblasts (NF) and cancer associated fibroblasts (CAF) from murine mammary tissue were exposed to TGF $\beta$ for 24 or 48 hrs and CD248 mRNA levels were quantified and normalized to levels from untreated NF. CD248 mRNA levels in NF were significantly suppressed by TGF $\beta$, whereas there was no effect on CD248 in CAF. ${ }^{*} p<0.05, n=3$. 
assess changes by Western blot. CD248 mRNA levels were therefore quantified by qRT-PCR (Figure $8 \mathrm{C}$ ). Following exposure of the cells to $3 \mathrm{ng} / \mathrm{ml}$ or $12 \mathrm{ng} / \mathrm{ml} \mathrm{TGF} \beta$ for 24 and $48 \mathrm{hrs}$, CD248 mRNA accumulation was significantly suppressed in the NF, while in contrast, there was no effect on CD248 mRNA levels in the CAF. Overall, the preceding findings indicate that the expression of CD248 in cancer cells is resistant to regulation by TGF $\beta$.

\section{Discussion}

Since the discovery of CD248 [45], clinical and genetic evidence has pointed to it as a promoter of tumor growth and inflammation (reviewed in [2]). Increased expression of CD248 is detected in stromal cells surrounding most tumors, and high levels often correlate with a poor prognosis $[20,23]$. Means of interfering with the tumorigenic effects of CD248 have eluded investigators due to a lack of knowledge surrounding the regulation of CD248. This has limited opportunities for the design of innovative therapeutic approaches. In this report, we show that expression of CD248 by non-cancerous cells of mesenchymal origin is specifically and dramatically downregulated at a transcriptional and protein level by the pleiotropic cytokine, $\mathrm{TGF} \beta$, and that the response is dependent on canonical Smad2/3-dependent signaling. Notably, CD248 expression by cancer cells and cancer associated fibroblasts is not altered by TGF $\beta$. The findings suggest that a TGF $\beta$-based strategy to suppress CD248 may be useful as a therapeutic intervention to prevent early stage, but not later stage, tumorigenesis.

Members of the TGF $\beta$ family regulate a wide range of cellular processes (e.g. cell proliferation, differentiation, migration, apoptosis) that are highly context-dependent, i.e., stage of development, stage of disease, cell/tissue type and location, microenvironmental factors, and epigenetic factors. Under normal conditions, TGF $\beta$ plays a dominant role as a tumor suppressor at early stages of tumorigenesis, inhibiting cell proliferation and cell migration (reviewed in $[46,47])$. TGF $\beta$ ligands signal via TGF $\beta$ RI (ALK-5) and TGF $\beta$ RII. A third accessory type III receptor (TGF $\beta$ RIII) lacks kinase activity, but facilitates the tumor-suppressor activities of TGF $\beta$. TGF $\beta$ binds to TGF $\beta$ RII which transphosphorylates ALK-5. In canonical signaling, ALK-5 then phosphorylates Smad2 and Smad3, inducing the formation of heteromeric complexes with Smad4, for translocation into the nucleus, interaction with transcription factors, and regulation of promoters of several target genes $[48,49]$. Disruption of TGF $\beta$ signaling has been associated with several cancers and a poor prognosis [47], and mice that lack TGF $\beta$ spontaneously develop tumors and inflammation [50].

TGF $\beta$ signaling is not, however, restricted to Smads 2 and 3, but can couple to non-canonical (Smad2/3-independent) effectors [48,51-54]. Recent data support the notion that canonical signaling favours tumor suppression, while non-canonical signaling tips the balance, such that TGF $\beta$ switches to become a promoter of tumor growth, invasion and metastasis, overriding the tumor-suppressing activities transmitted via $\operatorname{Smad} 2 / 3$. This dichotomous nature is known as the "TGF $\beta$ Paradox", a term coined to describe the conversion in function of TGF $\beta$ from tumor suppressor to tumor promoter [55-57]. The mechanisms underlying this switch are steadily being delineated, as regulation of the multiple effector molecules that are coupled to TGF $\beta$ are identified and characterized (reviewed in [47]). Our findings suggest that CD248 may be one such TGF $\beta$ effector molecule that undergoes a context-dependent change in coupling, and thus may be a potential therapeutic target.

Upon determining that TGF $\beta$ suppresses CD248, we first showed that the response is dependent on Smad 2 signaling. This is consistent with the almost undetectable levels of CD248 in normal tissues, its expression presumably held in check at least in part by TGF $\beta$ 's tumor suppressor properties. The fact that TGF $\beta$ induces phosphorylation of Smad2 in MEF that lack CD248, indicates that CD248 is not required for Smad2 phosphorylation. Rather, in the TGF $\beta$-signaling pathway, CD248 is positioned "downstream" of Smad2/3 phosphorylation. We also showed that CD248 is downregulated by TGF $\beta$ primarily at a transcriptional level, and without affecting the stability of its mRNA. We have not determined which regions of the CD248 promoter are required for TGF $\beta$-induced suppression. However, intriguingly, the murine promoter of the $\mathrm{CD} 248$ gene contains the sequence $5^{\prime}$-TTTGGCGG (position -543 to -536) [5] that overlaps with a consensus E2F transcription factor binding site. This is almost identical to the unique Smad3 DNA binding site in the $c-m y c$ promoter that is crucial for TGF $\beta$-induced gene suppression [58]. Detailed mapping of the promoter will provide insights into precisely how CD248 is regulated by TGF $\beta$.

We also examined whether TGF $\beta$ coupling to noncanonical effector molecules, ERK $1 / 2$ and p38, alters expression of CD248. Neither ERK1/2 nor p38, pathways implicated in TGF $\beta$-induced metastasis, affected CD248 expression. Thus, based on current data, TGF $\beta$-induced suppression of CD248 occurs primarily, if not exclusively, via canonical Smad2/3 signaling.

The specificity of the response of CD248 to TGF $\beta$ extends beyond Smad2/3-related signaling. In a survey of growth factors and cytokines, we could not identify other factors that similarly suppress (or conversely, increase) CD248 expression in MEF, $10 \mathrm{~T} 1 / 2$ cells or primary vascular smooth muscle cells. Even BMP2 and activin, members of the TGF $\beta$ superfamily and pleiotropic cytokines that also exhibit tumor promoter and suppressor activities, had little effect on CD248 expression. Although our survey was limited in range, concentration and time of exposure, the findings suggest specificity, and highlight the central 
role that TGF $\beta$ likely plays in regulating expression of CD248 in non-cancerous cells.

Most notably, in two tumor cell lines and in cancer associated fibroblasts, the regulation of expression of CD248 was resistant to TGF $\beta$. Indeed, in these cells, TGF $\beta$ neither decreased nor increased CD248, suggesting a decoupling of the regulatory link between TGF $\beta$ and CD248. Thus, with the switch from a tumor suppressor to a tumor promoter, TGF $\beta$ loses it ability to regulate CD248. Although TGF $\beta$ does not appear to directly participate in enhancing CD248 expression during late tumorigenesis, loss of its ability to suppress CD248 may be relevant in tumor progression and metastasis.

\section{Conclusions}

We have shown that the tumor suppressor properties of TGF $\beta$, observed in early stage cancer, are likely mediated in part via suppression of CD248, the latter which is mediated via canonical Smad-dependent pathways. Upregulation of CD248 might be an early detection marker of tumor growth and metastasis, and may be valuable in monitoring TGF $\beta$-based therapies. The clinical relevance of understanding how CD248 is regulated is highlighted by ongoing Phase 1 and 2 clinical trials in which the anti-CD248 antibody, MORAb-004, is being tested for efficacy in solid tumors and lymphomas (www.clinicaltrials.gov). Delineating the molecular mechanism(s) by which TGF $\beta$ loses its ability to suppress CD248 will be key for the design of additional therapeutic interventions to prevent and/or reduce CD248dependent tumor cell proliferation and metastasis.

\section{Competing interests}

The authors declare that they have no competing interests.

\section{Authors' contributions}

SSB helped design and perform the experiments and wrote the manuscript. $\mathrm{Y}$ helped design the studies and prepare the manuscript. $A X, A O$ and $V L$ provided technical support. FC prepared and provided normal and cancer associated fibroblasts. EMC supervised, directed and designed all studies and wrote the manuscript. All authors read and approved the final manuscript.

\section{Acknowledgements \\ We thank Dr. Erik Sahai, Cancer Research UK London Research Institute, for input on the manuscript and for providing cancer associated fibroblasts. FC was supported by a Cancer Research UK grant CRUK_A5317. YV was supported by a Michael Smith Foundation for Health Research/Crohns' and Colitis Foundation of Canada Trainee Award and is a recipient of a postdoctoral fellowship from the Canadian Institutes for Health Research (CIHR). EMC is supported by operating grants from the CIHR and the Canada Foundations for Innovation (CFI). He holds a CSL Behring Research Chair and a Tier 1 Canada Research Chair in Endothelial Cell Biology, is an adjunct Scientist with the Canadian Blood Services, and is a member of the University of British Columbia Life Sciences Institute.}

\section{Author details}

${ }^{1}$ Centre for Blood Research, Department of Medicine, University of British Columbia, 4306-2350 Health Sciences Mall, V6T 1Z3, BC Vancouver, Canada. ${ }^{2}$ Tumour Cell Biology Laboratory, Cancer Research UK London Research Institute, London, UK. ${ }^{3}$ Tumour Microenvironment Team Division of Cancer Biology, The Institute of Cancer Research, London, UK.
Received: 25 November 2013 Accepted: 17 February 2014

Published: 20 February 2014

\section{References}

1. Christian S, Ahorn H, Koehler A, Eisenhaber F, Rodi HP, Garin-Chesa P, Park JE, Rettig WJ, Lenter MC: Molecular cloning and characterization of endosialin, a C-type lectin- like cell surface receptor of tumor endothelium. J Biol Chem 2001, 276(10):7408-7414.

2. Valdez Y, Maia M, Conway EM: CD248: reviewing its role in health and disease. Curr Drug Targets 2012, 13(3):432-439.

3. Morser J: Thrombomodulin links coagulation to inflammation and immunity. Curr Drug Targets 2012, 13(3):421-431.

4. Greenlee-Wacker MC, Galvan MD, Bohlson SS: CD93: recent advances and implications in disease. Curr Drug Targets 2012, 13(3):411-420.

5. Opavsky R, Haviernik P, Jurkovicova D, Garin MT, Copeland NG, Gilbert DJ, Jenkins NA, Bies J, Garfield S, Pastorekova S, Oue A, Wolff L: Molecular characterization of the mouse Tem1/endosialin gene regulated by cell density in vitro and expressed in normal tissues in vivo. J Biol Chem 2001, 276(42):38795-38807.

6. Brady J, Neal J, Sadakar N, Gasque P: Human endosialin (tumor endothelial marker 1 ) is abundantly expressed in highly malignant and invasive brain tumors. J Neuropathol Exp Neurol 2004, 63(12):1274-1283.

7. MacFadyen JR, Haworth O, Roberston D, Hardie D, Webster MT, Morris HR, Panico M, Sutton-Smith M, Dell A, van der Geer P, Wienke D, Buckley CD, Isacke CM: Endosialin (TEM1, CD248) is a marker of stromal fibroblasts and is not selectively expressed on tumour endothelium. FEBS Let 2005, 579(12):2569-2575.

8. Christian S, Winkler R, Helfrich I, Boos AM, Besemfelder E, Schadendorf D, Augustin HG: Endosialin (Tem1) is a marker of tumor-associated myofibroblasts and tumor vessel-associated mural cells. Am J Pathol 2008, 172(2):486-494.

9. Simonavicius N, Robertson D, Bax DA, Jones C, Huijbers IJ, Isacke CM: Endosialin (CD248) is a marker of tumor-associated pericytes in high-grade glioma. Mod Pathol 2008, 21(3):308-315.

10. Maia M, de Vriese A, Janssens T, Moons M, van Landuyt K, Tavernier J, Lories RJ, Conway EM: CD248 and its cytoplasmic domain: a therapeutic target for arthritis. Arthritis Rheum 2010, 62(12):3595-3606

11. Naylor AJ, Azzam E, Smith S, Croft A, Poyser C, Duffield JS, Huso DL, Gay S, Ospelt C, Cooper MS, Isacke C, Goodyear SR, Rogers MJ, Buckley CD: The mesenchymal stem cell marker CD248 (endosialin) is a negative regulator of bone formation in mice. Arthritis Rheum 2012, 64(10):3334-3343.

12. Simonavicius N, Ashenden M, van Weverwijk A, Lax S, Huso DL, Buckley CD, Huijbers IJ, Yarwood H, Isacke CM: Pericytes promote selective vessel regression to regulate vascular patterning. Blood 2012, 120(7):1516-1527.

13. Huber MA, Kraut N, Schweifer N, Dolznig H, Peter RU, Schubert RD, Scharffetter-Kochanek K, Pehamberger H, Garin-Chesa P: Expression of stromal cell markers in distinct compartments of human skin cancers. J Cutan Pathol 2006, 33(2):145-155.

14. Rupp C, Dolznig H, Puri C, Sommergruber W, Kerjaschki D, Rettig WJ, Garin-Chesa P: Mouse endosialin, a C-type lectin-like cell surface receptor: expression during embryonic development and induction in experimental cancer neoangiogenesis. Cancer Immun 2006, 6:10.

15. MacFadyen J, Savage K, Wienke D, Isacke CM: Endosialin is expressed on stromal fibroblasts and CNS pericytes in mouse embryos and is downregulated during development. Gene Expr Patterns 2007, 7(3):363-369.

16. St Croix B, Rago C, Velculescu V, Traverso G, Romans KE, Montgomery E, Lal A Riggins GJ, Lengauer C, Vogelstein B, Kinzler KW: Genes expressed in human tumor endothelium. Science (New York, NY) 2000, 289(5482):1197-1202.

17. Dolznig H, Schweifer N, Puri C, Kraut N, Rettig WJ, Kerjaschki D, Garin-Chesa $\mathrm{P}$ : Characterization of cancer stroma markers: in silico analysis of an mRNA expression database for fibroblast activation protein and endosialin. Cancer Immun 2005, 5:10.

18. Huang HP, Hong CL, Kao CY, Lin SW, Lin SR, Wu HL, Shi GY, You LR, Wu CL, Yu IS: Gene targeting and expression analysis of mouse Tem1/endosialin using a lacZ reporter. Gene Expr Patterns 2011, 11(5-6):316-326.

19. Rouleau C, Curiel M, Weber W, Smale R, Kurtzberg L, Mascarello J, Berger C, Wallar G, Bagley R, Honma N, Hasegawa K, Ishida I, Kataoka S, Thurberg BL, Mehraein K, Horten B, Miller G, Teicher BA: Endosialin protein expression and therapeutic target potential in human solid tumors: sarcoma versus carcinoma. Clin Cancer Res 2008, 14(22):7223-7236. 
20. Rouleau C, Smale R, Fu YS, Hui G, Wang F, Hutto E, Fogle R, Jones CM, Krumbholz R, Roth S, Curiel M, Ren Y, Bagley RG, Wallar G, Miller G, Schmid S, Horten B, Teicher BA: Endosialin is expressed in high grade and advanced sarcomas: evidence from clinical specimens and preclinical modeling. Int J Oncol 2011, 39(1):73-89.

21. Carson-Walter EB, Winans BN, Whiteman MC, Liu Y, Jarvela S, Haapasalo H, Tyler BM, Huso DL, Johnson MD, Walter KA: Characterization of TEM1/ endosialin in human and murine brain tumors. BMC Cancer 2009, 9:417.

22. Davies G, Cunnick GH, Mansel RE, Mason MD, Jiang WG: Levels of expression of endothelial markers specific to tumour-associated endothelial cells and their correlation with prognosis in patients with breast cancer. Clin Exp Metastasis 2004, 21(1):31-37.

23. Zhang ZY, Zhang H, Adell G, Sun XF: Endosialin expression in relation to clinicopathological and biological variables in rectal cancers with a Swedish clinical trial of preoperative radiotherapy. BMC Cancer 2011, 11:89.

24. Smith SW, Eardley KS, Croft AP, Nwosu J, Howie AJ, Cockwell P, Isacke CM, Buckley CD, Savage CO: CD248+ stromal cells are associated with progressive chronic kidney disease. Kidney Int 2011, 80(2):199-207.

25. Nanda A, Karim B, Peng Z, Liu G, Qiu W, Gan C, Vogelstein B, St Croix B, Kinzler KW, Huso DL: Tumor endothelial marker 1 (Tem1) functions in the growth and progression of abdominal tumors. Proc Natl Acad Sci USA 2006, 103(9):3351-3356.

26. Lax S, Ross EA, White A, Marshall JL, Jenkinson WE, Isacke CM, Huso DL, Cunningham AF, Anderson G, Buckley CD: CD248 expression on mesenchymal stromal cells is required for post-natal and infectiondependent thymus remodelling and regeneration. FEBS Open Bio 2012, 2:187-190.

27. Maia M, DeVriese A, Janssens T, Moons M, Lories RJ, Tavernier J, Conway EM: CD248 facilitates tumor growth via its cytoplasmic domain. BMC Cancer 2011, 11:162.

28. Marty C, Langer-Machova Z, Sigrist S, Schott H, Schwendener RA, Ballmer-Hofer K: Isolation and characterization of a scFv antibody specific for tumor endothelial marker 1 (TEM1), a new reagent for targeted tumor therapy. Cancer Let 2006, 235(2):298-308.

29. Zhao A, Nunez-Cruz S, Li C, Coukos G, Siegel DL, Scholler N: Rapid isolation of high-affinity human antibodies against the tumor vascular marker Endosialin/TEM1, using a paired yeast-display/secretory scFv library platform. J Immunol Methods 2011, 363(2):221-232

30. Ohradanova A, Gradin K, Barathova M, Zatovicova M, Holotnakova T, Kopacek J, Parkkila S, Poellinger L, Pastorekova S, Pastorek J: Hypoxia upregulates expression of human endosialin gene via hypoxia-inducible factor 2. Bri J Cancer 2008, 99(8):1348-1356.

31. Ray JL, Leach R, Herbert JM, Benson M: Isolation of vascular smooth muscle cells from a single murine aorta. Methods Cell Sci 2001, 23(4):185-188

32. Suresh Babu S, Wojtowicz A, Freichel M, Birnbaumer L, Hecker M, Cattaruzza M: Mechanism of stretch-induced activation of the mechanotransducer zyxin in vascular cells. Sci Signal 2012, 5(254):ra91.

33. Calvo F, Ege N, Grande-Garcia A, Hooper S, Jenkins RP, Chaudhry SI, Harrington K, Williamson P, Moeendarbary E, Charras G, Sahai E: Mechanotransduction and YAP-dependent matrix remodelling is required for the generation and maintenance of cancer-associated fibroblasts. Nat Cell Biol 2013, 15(6):637-646.

34. Garate M, Campos El, Bush JA, Xiao H, Li G: Phosphorylation of the tumor suppressor p33(ING1b) at Ser-126 influences its protein stability and proliferation of melanoma cells. FASEB J 2007, 21(13):3705-3716.

35. Conway EM, Rosenberg RD: Tumor necrosis factor suppresses transcription of the thrombomodulin gene in endothelial cells. $\mathrm{Mo} / \mathrm{Cell}$ Biol 1988, 8:5588-5592

36. Xu P, Liu J, Derynck R: Post-translational regulation of TGF-beta receptor and Smad signaling. FEBS Let 2012, 586(14):1871-1884

37. Moustakas $\mathrm{A}$, Heldin $\mathrm{CH}$ : The regulation of TGFbeta signal transduction. Development 2009, 136(22):3699-3714

38. Chen G, Deng C, Li YP: TGF-beta and BMP signaling in osteoblast differentiation and bone formation. Int J Bio/ Sci 2012, 8(2):272-288.

39. Karlsson G, Liu Y, Larsson J, Goumans MJ, Lee JS, Thorgeirsson SS, Ringner M, Karlsson S: Gene expression profiling demonstrates that TGF-beta1 signals exclusively through receptor complexes involving Alk5 and identifies targets of TGF-beta signaling. Physiol Genomics 2005, 21(3):396-403.

40. Inman GJ, Nicolas FJ, Callahan JF, Harling JD, Gaster LM, Reith AD, Laping NJ, Hill CS: SB-431542 is a potent and specific inhibitor of transforming growth factor-beta superfamily type I activin receptor-like kinase (ALK) receptors ALK4, ALK5, and ALK7. Mol Pharmacol 2002, 62(1):65-74.
41. Favata MF, Horiuchi KY, Manos EJ, Daulerio AJ, Stradley DA, Feeser WS Van Dyk DE, Pitts WJ, Earl RA, Hobbs F, Copeland RA, Magolda RL, Scherle PA, Trzaskos JM: Identification of a novel inhibitor of mitogen-activated protein kinase kinase. J Bio/ Chem 1998, 273(29):18623-18632.

42. Hippenstiel S, Soeth S, Kellas B, Fuhrmann O, Seybold J, Krull M, Eichel-Streiber C, Goebeler M, Ludwig S, Suttorp N: Rho proteins and the p38-MAPK pathway are important mediators for LPS-induced interleukin-8 expression in human endothelial cells [In Process Citation]. Blood 2000, 95(10):3044-3051

43. Sun F, Pan Q, Wang J, Liu S, Li Z, Yu Y: Contrary effects of BMP-2 and ATRA on adipogenesis in mouse mesenchymal fibroblasts. Biochem Genetics 2009, 47(11-12):789-801.

44. Tojo M, Hamashima Y, Hanyu A, Kajimoto T, Saitoh M, Miyazono K, Node M, Imamura T: The ALK-5 inhibitor A-83-01 inhibits Smad signaling and epithelial-to-mesenchymal transition by transforming growth factor-beta. Cancer Sci 2005, 96(11):791-800.

45. Rettig WJ, Garin-Chesa P, Healey JH, Su SL, Jaffe EA, Old LJ: Identification of endosialin, a cell surface glycoprotein of vascular endothelial cells in human cancer. Proc Natl Acad Sci U S A 1992, 89(22):10832-10836.

46. Wendt MK, Tian M, Schiemann WP: Deconstructing the mechanisms and consequences of TGF-beta-induced EMT during cancer progression. Cell Tissue Res 2012, 347(1):85-101.

47. Drabsch $Y$, ten Dijke P: TGF-beta signalling and its role in cancer progression and metastasis. Cancer Metastasis Rev 2012, 31(3-4):553-568.

48. Prud'homme GJ: Pathobiology of transforming growth factor beta in cancer, fibrosis and immunologic disease, and therapeutic considerations. Lab Invest 2007, 87(11):1077-1091.

49. Ikushima H, Miyazono K: Cellular context-dependent "colors" of transforming growth factor-beta signaling. Cancer Sci 2010, 101(2):306-312.

50. Zhang Y, Wen G, Shao G, Wang C, Lin C, Fang H, Balajee AS, Bhagat G, Hei TK, Zhao Y: TGFBI deficiency predisposes mice to spontaneous tumor development. Cancer Res 2009, 69(1):37-44

51. Daroqui MC, Vazquez P, Bal de Kier Joffe E, Bakin AV, Puricelli LI: TGF-beta autocrine pathway and MAPK signaling promote cell invasiveness and in vivo mammary adenocarcinoma tumor progression. Oncol Rep 2012, 28(2):567-575

52. Fleming YM, Ferguson GJ, Spender LC, Larsson J, Karlsson S, Ozanne BW, Grosse R, Inman GJ: TGF-beta-mediated activation of RhoA signalling is required for efficient (V12)HaRas and (V600E)BRAF transformation. Oncogene 2009, 28(7):983-993.

53. Wakefield LM, Roberts AB: TGF-beta signaling: positive and negative effects on tumorigenesis. Curr Opin Genetics Dev 2002, 12(1):22-29.

54. Wendt MK, Smith JA, Schiemann WP: p130Cas is required for mammary tumor growth and transforming growth factor-beta-mediated metastasis through regulation of Smad2/3 activity. J Biol Chem 2009, 284(49):34145-34156.

55. Rahimi RA, Leof EB: TGF-beta signaling: a tale of two responses. J Cell Biochem 2007, 102(3):593-608.

56. Schiemann WP: Targeted TGF-beta chemotherapies: friend or foe in treating human malignancies? Exp Rev Anticancer Ther 2007, 7(5):609-611.

57. Tian M, Schiemann WP: The TGF-beta paradox in human cancer: an update. Future Oncol 2009, 5(2):259-271.

58. Frederick JP, Liberati NT, Waddell DS, Shi Y, Wang XF: Transforming growth factor beta-mediated transcriptional repression of c-myc is dependent on direct binding of Smad3 to a novel repressive Smad binding element. Mol Cell Biol 2004, 24(6):2546-2559.

doi:10.1186/1471-2407-14-113

Cite this article as: Suresh Babu et al:: TGF $\beta$-mediated suppression of CD248 in non-cancer cells via canonical Smad-dependent signaling pathways is uncoupled in cancer cells. BMC Cancer 2014 14:113. 